\title{
Analisis Konflik Sosial Santri Reguler dan Intensif di TMI Putra Al-Amien Prenduan
}

\author{
Muhammad Munir \\ Universitas Islam Negeri Sunan Ampel \\ muniralafasy39@gmail.com
}

\begin{abstract}
This article describes the conflict that occurred between Regular and Intensive santri at TMI Putra al-Amin Prenduan. The data collection method used is comparing observational data with the results of interviews with triangulation. Humans are born to know each other and socialize. But everyone also has to live in groups. Problems arise when there is a conflict of social relations between groups and a lack of social communication that occurs due to several things. The conflict that occurred among the Regular and Intensive santri at TMI Putra al-Amin Prenduan, which resulted in a lack of social communication and admonished the santri. This is due to provocative words that often arise among santri, causing emotion within themselves to be very high which results in the emergence of hostility among santri. From the data obtained, about the Regular and Intensive santri social groups there are three that cause conflicts to occur between santri, namely: the mischief of the santri, the behavior of the santri and the social interaction of the santri. While the causes of the Regular and Intensive santri conflict in TMI Putra Al-Amien Prenduan are caused by three things, namely: the factor of the older brother's doctrine, fanatics and bullying.
\end{abstract}

Keywords: Social Group, Social Conflict, TMI al-Amin Prenduan

\begin{abstract}
Abstrak
Artikel ini mengemukakan perihal konflik yang terjadi antara santri Reguler dan Intensif di TMI Putra al-Amin Prenduan. Adapun metode pengumpulan data yang digunakan adalah membandingkan data hasil pengamatan dengan hasil wawancara dengan triangulasi. Manusia dilahirkan untuk saling mengenal dan bersosial. Namun semua orang juga harus hidup berkelompok. Masalah muncul ketika terjadinya konflik hubungan sosial antara kelompok dan kurangnya komunikasi sosial yang terjadi disebabkan beberapa hal. Konflik yang muncul terjadi di kalangan santri Reguler dan Intensif di TMI
\end{abstract}


Putra al-Amin Prenduan, yang mengakibatkan kurangnya komunikasi sosial dan tegur sapa antara santri tersebut. Hal ini disebabkan adanya kata-kata provokatif yang sering muncul di antara santri, sehingga menimbulkan emosi dalam diri menjadi sangat tinggi yang mengakibatkan timbulnya rasa permusuhan antar santri. Dari data-data yang diperoleh, tentang kelompok sosial santri Reguler dan Intensif ada tiga yang menyebabkan konflik terjadi antar santri, yaitu: kenakalan santri, prilaku santri dan interaksi sosial santri. Sedangkan faktor penyebab konflik santri Reguler dan Intensif di TMI Putra Al-Amien Prenduan disebabkan oleh tiga hal yaitu: faktor doktrin kakak kelas, fanatik dan bullying.

Kata Kunci: Kelompok Sosial, Konflik Sosial, TMI al-Amin

\section{Pendahuluan}

Manusia dilahirkan untuk saling mengenal dan bersosial. Namun semua orang juga harus hidup berkelompok, seperti Adam yang telah ditakdirkan agar hidup bersama, dengan seorang wanita yang belum dikenalnya, yaitu istrinya yang bernama Hawa. Banyak orang yang hidup selalu sendiri seperti Robinson Crusoe. Akan tetapi Robinson Crusoe tidak dapat membuat suatu penuntasan tentang kehidupan seseorang dengan seorang diri karena diberikannya seorang teman hidup. ${ }^{1}$

Naluri manusia yang ingin selalu hidup bersama dengan orang lain yang tidak bisa hidup tanpa manusia lainnya disebut gregariousness sehingga setiap manusia disebut social animal, yang artinya manusia hewan sosial. Karena manusia selalu berhubungan dengan manusia dengan manusia yang lainnya, yang paling penting dari hal ini adalah reaksi yang diakibatkan kepada seseorang sehingga menjadi keuntungan kepada orang lain. Manusia mempunyai keinginan untuk bersama dengan manusia lain yang ada di sekelilingnya, yaitu masyarakat. Kemauan itu menjadi salah satu dengan suasana sekelilingnya. Dengan inilah terbentuk suatu kelompok sosial. ${ }^{2}$

Kelompok sosial adalah kumpulan strategi manusia untuk mencapai kebersamaan yang dimiliki oleh setiap insan dengan kesadaran setiap anggota kelompok yang saling berkomunikasi dan berinteraksi satu sama lain. Pencipta dari kelompok sosial ini adalah suatu anggota masyarakat sendiri yang memengaruhi perilaku setiap individu dalam masyarakat.

Adanya kelompok tersebut semua kebersamaan terjalin di dalamnya dan memberikan timbal balik yang sangat memengaruhi anggota kelompok tersebut.

\footnotetext{
${ }^{1}$ Soerjono Soekarto, Sosiologi suatu Pengantar, (Jakarta : Grafindo Persada, 2004), 106

${ }^{2}$ Bambang Samsul Arif, Psikologi Sosial, (Bandung: Pustaka Setia, 2015), 63

${ }^{3}$ Ibid., 63
} 
Kelompok sosial hal ini sangat berpengaruh dalam mengubah sikap seseorang, perilaku dalam pribadi seseorang dengan adanya kelompok sosial semua aktivitas tercakup di dalamnya. ${ }^{4}$

Dalam kelompok sosial terdapat in-grup dan out-grup. Dalam proses sosialisasi terdapat kata kami dan mereka yang membentuk suatu perbedaan kelompok sosial dengan menjadikannya suatu landasan penting yang dibuat oleh individu sendiri. Sejalan dengan adanya kelompok sosial terbentuklah suatu struktur kelompok sosial, yang timbul dengan adanya pola sikap perasaan antar anggotanya yang disebut dari sikap in-group yang tegas dibatasi dari sikap perasaan out-group. ${ }^{5}$

Berangkat dari pengamatan sejak lima tahun terakhir ini, terlihat kelompok sosial santri yang ada di TMI Putra Al-Amien Prenduan yang perlu diteliti, yaitu: Kelompok sosial santri reguler dan Kelompok sosial santri intensif yaitu mereka mempunyai suatu tujuan masing-masing dan mempunyai ciri khas masing-masing. Contohnya dari kelompok sosial santri, yang mana dalam kelompok santri tersebut semua dididik untuk saling membanggakan kelompok mereka. Akibatnya ketika mereka tidak bisa mempertahankan kebahagiaan kelompok mereka, yang terjadi adalah konflik antar kelompok. Misalnya, tawuran setelah pertandingan sepak bola, futsal, volly disebabkan karena suporter yang berlebihan dan saling ejek-ejekkan. Dampak konflik tersebut berupa perbedaan cara memakai kopyah, cara memaka sarung, cara berjalan, fashion, belajar dan lain-lain.

Kebiasaan semua anggota kelompok sosial santri mulai benci terhadap kelompok yang telah mengejeknya dengan sebab itu maka setiap kelompok berusaha untuk mencari suatu bakat yang mereka miliki dengan hal itu mereka sulit untuk tidak berkomunikasi, menyapa, bahkan bersenda gurau dengan kelompok santri yang lain karena adanya larangan dari pengurus kelompok mereka, sehingga yang terjadi diantara mereka yaitu komunikasi tertutup yang menjadikan suatu prasangka buruk, sehingga sulit untuk saling memulai komunikasi terlebih dahulu karena adanya penanaman konflik psikologis dalam kelompok mereka dan akan berakibat konflik fisik yang tidak dinginkan oleh mereka semua.

Masalah yang menarik dalam hal ini yaitu satu hal yang membuat peneliti membuat keputusan dan tertarik untuk merujuk terjadinya konflik tersebut, yaitu adanya kata-kata provokatif yang sering muncul di antara mereka, sehingga menimbulkan emosi dalam diri mereka menjadi sangat tinggi. Hal ini menyebabkan timbulnya rasa permusuhan kepada kelompok lain.

\footnotetext{
${ }^{4}$ Bambang Samsul Arif, Psikologi Sosial, (Bandung: Pustaka Setia, 2015), 63

${ }^{5}$ Soerjono Soekarti dan Budi Sulistuowati, Sosiologi suatu Pengantar, (Jakarta: Grafindo Persada, 2014), 106
} 
Berdasarkan temuan awal di atas, memberikan gambaran untuk melakukan penelitian tentang "Analisis Konsep Kelompok Sosial Santri Reguler dan Intensif di Tarbiyatul Mu'allimien Al-Islamiyah Al-Amien Prenduan Tahun Pelajaran 2018/2019. (Studi Kasus Konflik Sosial Santri Reguler dan Intensif di TMI Putra Al-Amien Prenduan)".

Dalam membahas masalah kelompok sosial ini maka peneliti menggunakan jenis penelitian deskriptif kualitatif dan pendekatannya Studi Kasus, dengan menggunakan metode pengumpulan data wawancara, observasi dan dokumentasi dengan banyak responden 24 orang, yang meliputi santri reguler dan santri intensif serta para asatidz yang termasuk dalam pengawasan santri tersebut seperti kepala sekolah dan wakilnya. Adapun lokasi penelitian ini bertempat di Pondok Pesantren TMI Putra Al-Amien Prenduan Sumenep Madura Jawa Timur. Dengan pertimbangan bahwa dalam pesantren tersebut terdapat kelompok santri yang terkonsep dalam konflik sosial santri karena adanya perbedaan kelompok sosial santri intensif dan reguler. Sedangkan dalam analisis data peneliti menggunakan Reduksi Data, Sintesisasi, Menyusun Hipotesis Kerja. Dalam pengecekan keabsahan data peneliti menggunakan Triangulasi dan Perpanjangan Keikutsertaan.

\section{Hasil dan Pembahasan}

\section{A. Konsep Kelompok Sosial Santri Reguler dan Intensif di Tarbiyatul Mu'allimien Al-Islamiyah (TMI Putra) Al-Amien Prenduan}

\section{Kenakalan santri Reguler dan Intensif}

Dari data temuan penelitian memberikan penjelasan bahwa seluruh santri itu ada yang baik, tidak baik, nakal, tidak nakal, sedangkan yang menjadi pembeda ialah masalah santri Reguler dan Intensif, santri reguler itu adalah santri yang lulusan SD/MI, yang mana mereka masuk Pondok Pesantren TMI al-Amien Prenduan untuk melanjutkan ke jenjang SMP/MTs santri tersebut berusia sekitar 12-13 tahun yang sangat kecil dan jauh dari dengan orang tua mereka oleh karena itu faktor yang menyebabkan hal tersebut mengakibatkan mereka tidak betah dan memilih untuk nakal karena orang tua mereka tidak akan tahu bagaimana dia dipondok yang tahu hanyalah pengurus-pengurus pondok saja, akibat kenakalan santri tersebut pondok tidak segan untuk mengeluarkannya dari pondok. Hal ini sering terjadi pada santri kelas II Reguer dan III Reguler pada khususnya, kerena mereka baru pubertas jadi sedikit mengedepankan ego. Lain halnya dengan santri intensif yang patuh akan disiplin yang ada di pondok. 


\section{Prilaku Sosial Santri Reguler dan Intensif}

Santri Reguler dan Intensif memberikan pandangan atas suatu perbedaan yang terjadi pada santri saat ini. Santri intensif itu selalu sopan kepada semua santri dari santri kelas I Reguler sampai dengan santri kelas 6, kesopanan mereka ditunjukan kepada ustad\%, 90\% santri intensif itu rajin kemasjid dan hebat-hebat dalam keterampilan berbahasa. Sedangkan santri reguler mereka angkuh, nakal, tidak sopan, sok-sokan. Sifat dan prilaku mereka sangatlah berbeda dengan santri intensif mereka lebih sering melakukan hal yang bersifat melanggar dari melakukan hal yang berdisiplin, misalnya mereka jarang mengaji, tidak ikut sholat berjama'ah, tidak ikut kegiatan-kegiatan wajib yang sudah berlaku dipondok pesantren TMI Putra Al-Amien Prenduan.

\section{Intraksi Sosial Santri Reguler dan Intensif}

Intraksi sosial santri Reguler dan Intensif sangatlah jarang salah satu penyebabnya mereka saling malu untuk memulai komunikasi dengan lawan berbicara mereka yang berbeda golongan, ada juga yang mengatakan bahwa santri intensif itu tidak suka dengan santri reguler karena mereka masih anak kecil oleh karena itu mereka jauhi, sedangkan santri reguler tidak mau melakukan intraksi dengan santri intensif karena mereka baru masuk pondok jadi gensi jika mereka memulai intraksi terlebih dahulu, hal ini yang terjadi antara santri Reguler dan Intensif di pondok pesantren TMI Putra Al-Amien Prenduan.

\section{Faktor-faktor penyebab terjadinya Konflik Sosial Santri Reguler dan Intensif di Tarbiyatul Mu'allimien Al-Islamiyah Al-Amien Prenduan.}

Dari temuan hasil data diatas hal yang menjadi alasan terjadinya konflik santri intesif dan reguler, yaitu.

\section{a. Doktrin dari kakak kelas}

Doktrin yang terjadi dikalangan santri Reguler dan Intensif ialah doktrin dari kakak kelasnya dengan cara mengenalkan identitas santri Reguler dan Intensif, seperti contoh santri intensif ketika memakai sarung mereka harus diatas mata kaki, ketika memakai kopyah mereka harus memakainya diatas alis, kalau duduk dimasjid mereka harus di tengah-tengah masjid. Sedangkan santri reguler memakai sarung harus dibawah mata kaki, kopyahnya harus dipakai diujung dahi, duduknya ketika sholat dimasjid yang angkatan santri reguler genap disebelah selatan masjid sedangkan angkatan santri reguler ganjil harus duduk disebelah utara masjid. Batasan-batasan sosial, ciri-ciri Reguler dan Intensif mereka yang menjadikan salah satu penyebab konflik tersebut.

\section{b. Fanatik Santri Reguler dan Intensif}

Fanatik santri Reguler dan Intensif itu biasanya terjadi karena mereke ingin mempertahankan dan membangga-banggakan golongan mereka saja. 
Fanatik inilah yang membuat santri Reguler dan Intensif harus melakukan konflik antara santri Reguler dan Intensif, karena mereka hanya care, beleved dan Loyal pada golongan mereka sendiri. Fanatik lainnya juga karena mereka gengsi.

\section{c. Bullying Santri Reguler dan Intensif}

Bullying santri Reguler dan Intensif hal yang menjadikan suatu penyebab terjadinya konflik santri Reguler dan Intensif, Bullyan dari golongan santri intensif itu terjadi ketika melakukan kegiatan santri yaitu jimbaz (lari bersama dengan angkatan mereka pada hari selasa dan jum'at) mereka saling membuat yel-yel yang seakan-akan menjatuhkan sang lawan sehingga memanaslah dan terjadilah konflik kelompok. Sedangkan terjadinya konflik pribadi biasanya karena ketika berjalan berpapasan saling tabrakan, senggol-senggolan sehingga terjadi konflik pribadi yang menjadikan konflik kelompok yang terencana.

\section{Penutup}

Santri Reguler adalah santri yang menjadi permasalahan saat ini dalam konflik sosial santri dengan santri intensif, salah satu sebabnya mereka tidak mau menerima kelompok selain dari mereka karena sikap cuek yang terjadi pada kedua kelompok tersebut, begitu sebaliknya santri intensif tidak senang dengan santri reguler dikarenakan mereka yang nakal. Prilaku santri Reguler ini lebih cendrung kepada hal-hal yang negatif seperti fashion yang berlebihan, tidak sopan kepada adik kelas dan kakak kelasnya bahkan kepada ustadz sekalipun. Dibandingkan dengan santri intensif yang terkesan sopan, alim, santun, tidak suka melanggar disiplin. Interaksi sosial yang terjadi pada santri Reguler dan Intensif cukup baik akan tetapi ada sebagian mereka yang hanya menganggap golongan merekalah yang terbaik tanpa harus memikirkan orang sekelilingnya. Seperti cuek pada kakak kelas dan adek kelasnya.

Faktor Penyebab Konflik Sosial Santri Reguler dan Intensif di Tarbiyatul Mu'allimien Al-Islamiyah (TMI Putra) Al-Amien Prenduan. Salah satu penyebab konflik sosial santri itu karena adanya faktor doktrin dari kakak kelasnya. Seperti tidak boleh berteman dengan kelompok lain, tidak boleh mengikuti kelompok minat yang didominan oleh santri reguler dan maupun intensif. Adanya faktor fanatik terhadap kelompok lain dan membangga-banggakan kelompok sendiri. Seperti resus rajawali yang sering membangga-banggakan kelompok mereka dengan lagu-lagu ciri khas mereka, faktor bullying yang menjadikan konflik sosial santri Reguler dan Intensif. Seperti yel-yel diwaktu lari bersama yang berbau provokasi 


\section{Daftar Pustaka}

Ahmadi, Abu, Sosiologi Pendidikan, Jakarta, Rineka Cipta, 2007

Ahmad Sofian, Artikel Doktrin dan Teori dalam Ilmu Hukum, Bulan Mei, 2016

Arifin, Bambang Syamsul, Psikologi Sosial, Bandung, CV Pustaka Setia, 2015

George, Ritzer, “Teori Sosiologi Modern" Jakarta, Prenadamedia Grup, 2014

Hipsari, "Jurnal Fanatisme dan Agresivitas Suporter Klub Sepak Bola" Vol. 1, 2015

Jamaluddin, Adon Nasrullah, Agama dan Konflik Sosial, Bandung, Pustaka Setia, 2015

J. Moleong, Lexy, Metode Penelitian Kualitatif, Bandung, Remaja Rosdaka Karya, 2011

La Ode Syamri “Kumpulan Pengertian dan Defenisi"https://laodesyamri.net/ 2015/01/02/ defenisi-konsep-menurut-para-ahli/ diakses 26/12/2017

Michel Wieviorka, Jurnal 'Social conflict', Sociopedia.isa, DOI:10.1177/ 205684601054, 2010

Moh. Pabundu Tika dkk., Pengetahuan Sosial Sosiologi. Jakarta, Bumi Askara, 2007

Rumi Iqbal Doewes "The Social Identity Of Football Supporters In Providing Sportive Support To Arema Player (A Phenomenology Study To Supporter Of Aremania In Malang)." Vol. 1, No. 1, Januari 2016

Riski Melia Sari, Jurnal Komunitas 234 Sc Di Pekanbaru (Studi Tentang Kelompok Sosial).

Soerjono Soekarti dan Budi Sulistuowati, Sosiologi Suatu Pengantar, Jakarta, Grafindo Persada, 2014

Soekarto, Soerjono, Sosiologi Suatu Pengantar, Jakarta, Rineka Cipta, 2005

Soerjono Soekarto, Sosiologi Suatu Pengantar, Jakarta : Grafindo Persada, 2004

Sella Ayu Pritiwi, Konfronmitas dan Fanatisme pada remaja Korean Wave (Penelitian pada komunitas Super junior Fans Club ELF "Ever Lasting Friend") di Samarinda, Vol 1, No. 2, 2013, 157-166

Sugiyono, Metode Penelitian Pendidikan, Bandung, Alfabeta, 2016

Tri Dayakisni \& Hudaniah, Psikologi Sosial, Malang, UMM Press, 2012

W. Sarwono, Sarlito, Psikologi Remaja, Jakarta, Grafindo, 2013

W.A. Gerungan, Psikologi Sosial, Bandung, Refika Aditama, 2010

Widyastuti, Yeni, Psikologi Sosial, 2014 (Yogyakarta, Graha Ilmu) 
54 | ISLAMIC COUNSELING: Jurnal Bimbingan dan Konseling Islam, vol. 3, no. 1, 2019 